\title{
The transsexual dilemma: being a transsexual
}

\author{
Nicholas Mason
}

\begin{abstract}
Author's abstract
With few exceptions, a solution to any problem will bring new difficulties. These may or may not be worse than the original problem, and one must decide, not between problem and answer, but between degrees of difficulty. Is the new situation really going to be better than the last?

This is undoubtedly the situation with the transsexual. It is undeniable that in the majority of cases the treated transsexual is an infinitely happier person than the one who has not undergone therapy, but as a result of this treatment there arises a host of new difficulties.

Using personal experience, it is my intention to illustrate the problems which beset the transsexual before, during and after treatment. It will then be possible to ascertain whether or not, in spite of these difficulties, there is in fact a dilemma. Is there indeed any choice?
\end{abstract}

\section{Difficulties prior to treatment}

I was not consciously aware of any great problems as a small child. Even in those less tolerant days 'tomboys' were accepted, and no one appeared to worry because I played with boys and wore boyish clothes. However, I only recently discovered that my mother took me to the local GP because she was concerned about the size of my clitoris. $\mathrm{He}$ apparently did not consider it a matter for alarm.

It was with the onset of puberty that the real problems arose as I became aware of the conflict which is part of being transsexual. I dreaded the development of the female secondary sex characteristics and the menarche. Female attire was shunned by me as much as possible because I felt so awkward and 'wrong' in it. The greatest conflict was that between the role-expectations of family and society as opposed to my own.

There were inevitable problems when it came to choosing a suitable career. Nearly everything I suggested was thought only appropriate for boys this was twenty years before the Equal Opportunities Act.

As the hated puberty progressed so it also became obvious that my sexuality was not that of a normal female. Having passed the 'crush' stage, I was still sexually attracted to women. Reluctantly I decided that I was homosexual, although I was very unhappy to assume that label. Even then I felt that my attitude was different from that of the conventional lesbian. A lesbian relationship was abhorred. I wanted a relationship of a man with a woman.

The refusal to 'dress up' meant that social functions were anathema. I had few shared interests with female peers, especially when teenagers. At the same time, as an ostensible female, it was not possible to form friendships with male contemporaries. My 'oddness' was often sensed. All this meant that I became increasingly isolated. There were a few friends who seemed to understand my situation, but on the whole, the time between puberty and re-assignment therapy was a time of great loneliness.

My ambivalent gender became more obvious to those around as I entered adulthood. This provoked many comments, some malicious, others made in ignorance.

'He, she or it?' asked a man, thinking it very amusing.

'When are you going to change sex ?' shouted a teenage boy across the street.

It was easier to forgive those who made genuine mistakes such as the school caretaker who wanted to allot me a locker in the boys' locker room, the ambulance men who wanted to take me to the male ward after a motor-cycle accident or the embarrassed lady who thought that she had mistakenly gone into the 'Gents'.

The effect of all this was to make me withdrawn and depressed. I became afraid to leave the house for fear of such remarks.

The problem was unbearable and I knew it was imperative that help be obtained. But from where? My friends were very sympathetic but they advised me to seek professional advice.

I wrote to Evelyn Home of Woman and received a kind reply in which she suggested medical help. This was something to be avoided at all costs because I felt sure that a doctor would tell me to pull myself together. A Church social worker was my next contact. She was a very unhelpful woman in a knitted hat who told me to pray and go to church! I then went to a local priest who was extremely sympathetic but obviously thought me homosexual. Still I persisted in believing that I was not a homosexual. Was I really unique? Surely there had to be others who felt the same way? 
So it was that at the age of sixteen I privately consulted a lady doctor, Dr F who had a reputation for being sympathetic. However she was approached with a great deal of trepidation; would she really understand?

\section{Medical attitudes}

Dr F was the first doctor to be approached on this matter. Of course she did not, as I had feared, tell me 'to pull myself together and not waste her time'. Her attitude was one of genuine understanding and concern. If this was to be the general attitude of the medical profession then my fears could be dispelled.

Dr $F$ suggested that before submitting me to further examination of a physical nature she would like me to see, a psychiatrist, Dr G. Knowing her to have my best interests at heart I agreed, in spite of my fear of being thought psychotic.

Dr G was a pleasant enough man but my visits to him were not occasions I would wish to repeat. His searching questions were fired between intervals of silence during which time he stared hard at me. It was very disconcerting. He seemed confident that he could help but how he intended to do this without a course of brain-washing was a mystery to me. He was certainly not planning re-assignment therapy. My overall impression of his attitude was that he was as sympathetic with me as he would be with anyone who was suffering from a delusion.

After psychological tests at his hospital, which showed that I was suffering from an inferiority complex, I was admitted as an in-patient. This was entirely voluntary - I felt it was preferable to the 'cruel' world outside where everyone seemed to make unkind comments.

Once in the hospital I was under the care of a lady psychiatrist who reminded me of a sleek cat who was forever purring. She suggested that I did not want to be feminine because I felt that I would be unable to compete with my more feminine younger sister. She asked me why I was expecting to have my attitude changed, whilst at the same time Dr G said that he hoped I would soon feel differently. My initial hopes for positive help which Dr F had inspired were soon dashed. It was obvious that although the psychiatrists sympathised they did not really understand. This feeling was further re-inforced by the parting comment of the lady psychiatrist, 'Good-bye my dear, enjoy being a woman!'

During my hospital stay my own GP, Dr H, who turned out to be more understanding than anticipated, arranged for me to see a consultant endocrinologist at a London hospital. This was to be the very worst of all my experiences with the medical profession. Perhaps now I could cope with such as he, but at the age of sixteen when I was in a very unhappy state, his brusque unsympathetic manner was not only unhelpful, it was also extremely distressing. He said that I was completely norma? and should leave the hospital immediately and ge a job - as if that would solve my gender problem Or perhaps he thought that if I had something else to do I would not have time to think about such absurd desires as wanting to live as a man.

Four years later, with the backing of Dr who was now my GP, I joined the WRNS. first my gender identity problem seemed und control because I adopted a policy of regarding myself as acting a drag part. Only in this way could I tolerate 'dressing up' and being seen by others as apparently female.

But this 'detachment' did not last many month It had been absurd to think that I could live sexless life. This state of toleration was ended by the advent of a Wren to whom I was attracted, and pressures began to build up.

Not wanting to again be sent to a psychiatrist $d$ went to the Chaplain, a very understanding mah who is now a personal friend. He advised me to see the MO and assured me that he would be syntpathetic.

The MO was, in my opinion, one of the moset realistic medical men so far encountered. He da not scorn my desire to live as a man, but pointge out that few surgeons would be willing to undes take such a procedure. It may not be so now but probably was in 1965 .

My papers of course followed when I wis drafted to a new station and my new MO, also an apparently kindly man, was less sensitive to ngy dislike of psychiatry. He referred me to a Naval psychiatrist. I had several consultations with the specialist, who also seemed a kindly, understandi man and there was more rapport with him thä with the civilian psychiatrists. Certainly he did nigt tell me to 'enjoy being a woman'.

The outcome was inevitable. After psychologi tests the Naval doctors decided (erroneously, in my opinion) that I had 'homosexual tendencie and medically discharged me from the service.

Pressure in civilian life were no less; if anything things were becoming worse. Again I sought thee help of a doctor, this time my new GP, Dr F by then having moved away. Dr J was sympathetric in a helpless kind of way. He prescribed a travaquilliser and told me that he was sorry, I would jest have to learn to live with my condition. He also suggested 'off the cuff' that there might be an out ret for my frustrated desires at one of the lesbian cluofs in London! If he thought that I would go to Londih to see who I could 'pick up' then he did not knog v me very well. Others may have seen me as lesbian but it was a label which still made me cringe. $\unrhd$

Five years after the WRNS discharge I evertually found a doctor who said that he could help me. In the meantime the existence of 'transsexualism' became known to me and I felt sure that this was my condition. The doctor (who was to my regret? 
psychiatrist) confirmed my view when he diagnosed me as 'transsexual'. He said that he would help me to live as a man, which I had to do before any surgery could be contemplated. Dr X's manner was brisk but since he also seemed to understand the hell one suffered as a transsexual and was also going to help me achieve my end, I had no cause for complaint.

\section{Post-treatment experience}

Inevitably, the change of role presented difficulties within the family. However, I was more fortunate than many transsexuals because once they had recovered from the initial shock my family accepted the situation and gave me their support. Friends and neighbours were less surprised than my family when I began to live as a man and consequently soon accepted me as 'Nicholas'. It was not long before they felt that the previous 'me' had never existed. They could think of me only in the present male role. Of course, there were awkward moments when bumping unexpectedly into former colleagues. Since I did not move from my home this kind of thing was bound to happen from time to time.

There were other difficulties, difficulties which I had anticipated when making my decision to change roles. It had been obvious that there would be problems with such things as using public toilets. Of course there is always the fear that people will think me odd if I only use a cubicle, although not once has my gender been challenged when using the 'Gents' as it was when I was obliged to use the female conveniences. Nor can I use the showers in changing rooms (fortunately I am no sportsman). I use the public swimming baths, although with caution. However, no one has appeared to take any notice of me. Sharing accommodation is avoided if possible, which can make it difficult and expensive for a single person on holiday.

Although it is obvious that society has fully accepted me in the male role, there are moments when I worry about looking normal. At times I become mildly obsessive about this, especially with regard to the size of my hips, which to my eyes are gross and feminine. Since no one else has made any remark to this effect I can only conclude that it cannot be that obvious. Since my bilateral mastectomy concavities have formed where the tissue was removed from the chest; this too causes me concern, especially in the swimming pool, but again this must be a case of hypersensitivity.

However, all these problems, real and imagined, have been worth tolerating in order to live a life freed from the conflict which was making existence so unhappy. No longer do I feel that I am acting a part but am free to be myself. This release from conflict has meant that I have, according to my friends, become more relaxed and confident. As a result deeper relationships have been possible with old friends and I have been able to be outgoing enough to make new friends.

It has also been worth overcoming the above difficulties (and others to be mentioned subsequently) in order not to be noticed. My gender is seldom questioned (three times in nine years!) and I am no longer afraid of being looked at or hearing speculations as to my gender.

\section{Post-treatment medical attitudes}

The attitude of Dr $\mathrm{X}$ was the one most important to me at this time, but it was the one which was most unhelpful. It was difficult to understand the reason for his ambiguity. He had made possible my role-change then persisted in referring to me by my former gender pronoun and was at constant pains to remind me that I was a woman. The only comfort was that he treated other transsexuals in a similar manner. It was nonetheless very disturbing. Sometimes he seemed to become almost sneering and was certainly patronising, referring to female-to-male transsexuals in an article as 'these ladies' and informing the readers that they 'have an unfortunate tendency to marry', as if transsexuals were another species without the need to be loved and to love, and certainly beneath marriage.

Before going to College I underwent a medical examination at the LEA headquarters. As a matter of course, Dr X submitted a report to the examining doctor, a very kind man who treated me as an intelligent being. He was utterly amazed that Dr $\mathbf{X}$ had referred to me throughout his letter as 'she'.

Not only was I becoming increasingly disillusioned with $\mathrm{Dr} X$ 's attitude but also with his methods, which compared with the treatment given in other hospitals by similar teams seemed almost casual. Eventually through a medical contact I found a team at another hospital willing to take me as a patient. I was very impressed by the thoroughness of this team, underwent tests for the first time ever, and was deemed suitable for 'corrective surgery', ie a phalloplasty. It was not only the thoroughness of their investigations which gave me confidence but also their attitude towards me. Their use of the term 'corrective surgery' is an illustration of their basic difference in approach from that of Dr X. With them, I did not feel as if I were regarded as a psychotic female believing that she were male, but as a man with a handicap which they would do their best to ameliorate. The psychiatrist of the team, Dr $\mathrm{K}$ was a man of humility and willing to admit that transsexualism may not be in the province of the psychiatrist. If it were, then it is a form of delusion. Dr K said that he could not regard someone like Jan Morris as deluded. He was also keen to read my (unpublished) autobiography and talked to me not as a deluded 
patient but as one from whom he could learn. The view of the team that transsexualism was a form of intersex was one I could quite happily accept. It is impossible to stress too much the help which this team gave me by their understanding attitude, which gave me self-respect. Unfortunately the phalloplasty which was proposed is not at present viable.

No other doctor encountered by me has shared Dr X's attitude. Professionally and socially they have treated me as male, even when having full knowledge of my condition. It was interesting to meet Dr F after many years. She said that it was like meeting an entirely different person. We have since become good friends and Dr F has supported me in my battle for legal recognition. The nurses and other medical personnel with whom I came into contact during my hospital stay were equally accepting. I was all part of the day's work! One of them assured me that I should not think myself barred from having a close relationship with a girl since girls wanted more than sex! Many doctors, nurses and other hospital staff have given support to my efforts to get a change in the law regarding the birth certificate.

\section{Administrative and legal problems created by a change in role}

Changing my documentation was tedious but presented no real problem. Most of the authorities contacted were discreet and sympathetic. Where necessary I was helped by $\mathrm{Dr} \mathrm{X}$ who wrote to the bodies concerned to support my request for a change of name. He also gave me the address of a sympathetic solicitor who drew up a change of name deed. To be fair to $\operatorname{Dr} X$ he was very helpful in these administrative matters. The greatest problem was, and still is, the refusal of the Registrar General to permit amendment of my birth certificate. In practical terms this means that:

a) In theory one can only marry a genetic male. This is not only undesirable but, after surgical treatment impossible. One is barred from marrying one of the opposite gender. Therefore in effect, the transsexual is denied the right of marriage.

b) Since the law recognises me only as female the Established Church will also only recognise me in this way and will not permit me to offer myself for Ordination. At the same time, since I am ostensibly male, the chances of becoming a Lay Worker or Deaconess are remote!

c) Although officially the Birth Certificate is not an identity document it is not unusual to be asked to show it to prospective employers or college authorities and others. It is sometimes possible to avoid this if one has a passport (which can be altered since it does not state gender) but even so this prospect is always a very real fear. d) As a 'legal woman' I am at present due to retire at sixty. This no doubt will be a matter of puzzlement to my professional colleagues!

In addition to these practical problems there is very real psychological problem posed by the leget situation. Although I know that society as a whote accepts me as male, the knowledge that legal I am female is extremely unsettling, and puts me in a state of limbo. Thus, the treatment, however good, is less than effective.

\section{The attitude of the Church}

As individuals, the members of the Church have been very accepting and loving. Some members my former parish even sent a letter to my $M A$ petitioning him for a change in the law. A fefi priests have stated that they would be willing to perform a wedding service without the registe? signing.

The official attitude of the Anglican Church is obstructive and unimaginative as that of the Lav. Both the Church and the Law insist on seeing my as a 'woman' and the former is more distressing because one expects the Law to be rigid but the Church compassionate. It is impossible to have a new Baptismal Certificate. This is desired not state I was baptised with my present name whi, would be wrong, but to certify that I am baptiseg. Mention has already been made of the ordination issue, but unlike the potential women priests, 길 cannot make a fuss, but instead have to preterd that ordination is of no interest. This is especially galling when colleagues go on to Theological Colleges whilst I remain an unemployed graduate.

Yet in spite of being a woman in the eyes of the Church, I am accepted as a server at one of the larger cathedrals, (serving there being all-matê) and also stay at monastries without anyone knowing that they have a 'woman' guest!

Whilst being grateful for the love shown me by the people I am totally disillusioned with the Anglic每 Church as an institution.

\section{Spiritual and moral problems posed by} change of role

As far as I am concerned there is no doubt of the 'rightness' of my decision to change roles and ferw people have challenged this. One priest did thiok that I should have remained in my former role and 'borne my cross'. (He was the one who thought me homosexual.) I cannot subscribe to this the logy. Is it really being Christian to reject the offor of help, especially if it enables one to become morfe of a whole person, in order to 'bear a cross'? Surefy being a transsexual is cross enough. What virtue is there in embracing suffering if it is unnecessary? One WRNS friend (a self-confessed agnostiç] 
accused me of 'going against the God-given'. With that attitude one could say the same of anyone who sought medical aid for any deficiency or deformity.

Many of my friends are priests and religious. They share my view that treatment has been fully justified because it has enabled me to become more whole. However the situation does pose certain moral problems - some would only affect the Christian transsexual, others are more general.

Is it better to conceal the past from potential employers than to 'tell all' even if this means evasion or even outright lies on an application form ? Do they really want to know that I have been in the WRNS and have had a total hysterectomy? Wouldn't such disclosures make life difficult all round?

At what point does one tell a girlfriend of the situation? Some transsexuals try to avoid any disclosure, but I feel this is as dishonest as it would be for a bad hypospadias not to tell a girl with whom he was in love. At the same time, it may be foolish to tell a potential partner too soon in the relationship. Finding the optimum point for this is not an easy task.

If one cannot legally marry, is it a sin to have a sexual relationship?

If one cannot gain a new identity in the Church would it be a grave sin to be re-baptised by a priest who is ignorant of the situation?
Is the financial and emotional cost of the treatment justified? This question has already been answered. Since it makes one a better person, then society as a whole benefits. One is less likely to be a drain on the NHS resources because it is possible an untreated transsexual may need treatment for exogenous depression. The situation is also likely to make one seek solace in drugs or alcohol.

Thank God that my treatment has spared me from such an existence. I am now at one with the world, at ease within myself and with others. My experiences have made me very much aware of the enormous resources of love. It is this love which has drawn me to the Christian faith.

\section{Conclusion}

This article should illustrate the writer's belief that there is no 'transexual dilemma', because whatever the resulting problems, the choice is obvious, so obvious that one has never queried it. My previous role may have been less fraught with the medical, legal and moral problems previously described, but it was a life of extreme unhappiness and conflict. What has been more important than becoming male socially has been the ability to become myself. It was a choice between existence and life. Given these circumstances, was there in fact a choice to be made ? I think not. 